\title{
C-104 Solid Phase Characterization of Sample 4C-13-1 From Tank 241-C-104 Closure Sampling Event
}

G. A. Cooke

J. A. Pestovich

Washington River Protection Solutions LLC

Date Published

May 2013

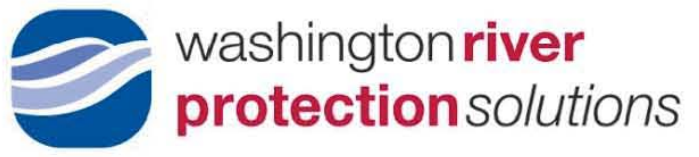

Prepared for the U.S. Department of Energy Office of River Protection

Contract No. DE-AC27-08RV14800

APPROVED

By Janis D. Aardal at 8:25 am, Jun 12, 2013 


\section{LEGAL DISCLAIMER}

This report was prepared as an account of work sponsored by an agency of the United States Government. Neither the United States Government nor any agency thereof, nor any of their employees, makes any warranty, express or implied, or assumes any legal liability or responsibility for the accuracy, completeness, or any third party's use or the results of such use of any information, apparatus, product, or process disclosed, or represents that its use would not infringe privately owned rights. Reference herein to any specific commercial product, process, or service by trade name, trademark, manufacturer, or otherwise, does not necessarily constitute or imply its endorsement, recommendation, or favoring by the United States Government or any agency thereof or its contractors or subcontractors. The views and opinions of authors expressed herein do not necessarily state or reflect those of the United States Government or any agency thereof.

This report has been reproduced from the best available copy.

Printed in the United States of America 


\section{Contents}

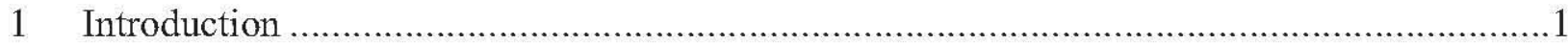

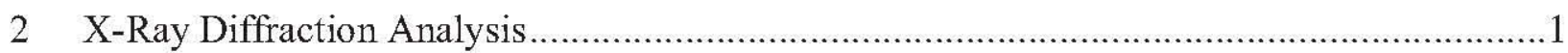

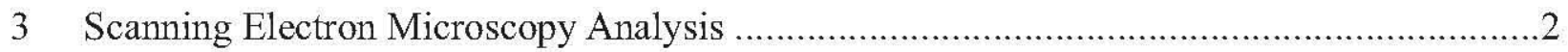

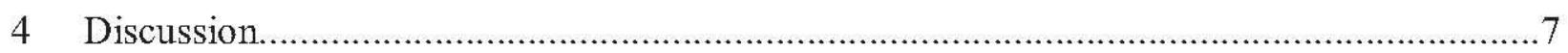

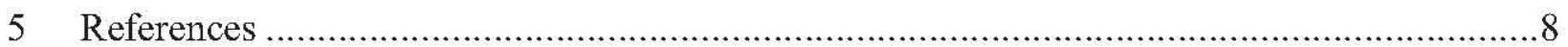

\section{Table of Figures}

Figure 1. X-Ray Diffraction Pattern, Sample S13T003832 (4C-13-1) …….............................

Figure 2. Sample 4C-13-1: Particle Aggregates (Left) and Energy Dispersive Spectrometry Spectra (Right) from Area in Yellow Box..............................................................

Figure 3. Sample 4C-13-1: Particle Aggregate Coated with Sodium Carbonate (Left) and Energy Dispersive Spectrometry Spectra (Right) from Spot Marked with Yellow Cross.

Figure 4. Sample 4C-13-1: Close-up of Aggregate Surface (Left) and Energy Dispersive Spectrometry Spectra (Right) from Areas in Yellow Box. ..........................................

Figure 5. Sample 4C-13-1: Small Irregular Sodium Carbonate Aggregate (Left) and Energy Dispersive Spectrometry Spectra from Areas in Yellow Box (Right).

Figure 6. Sample 4C-13-1: Single Crystal of Gibbsite (Left) and Energy Dispersive Spectrometry Spectra (Right) from Spot Marked with Yellow Cross.

Figure 7. Sample 4C-13-1, Patch of Fine-Grained Clarkeite: Backscatter Electron Image (Left), Secondary Electron Image (Center), and Energy Dispersive Spectrometry Spectra (Right) from Spot Marked with Yellow Cross.

Figure 8. Sample 4C-13-1, Patch of Fine-Grained Iron Oxyhydroxide: Backscattered Electron Image (Left), Secondary Electron Image (Center), and Energy Dispersive Spectrometry Spectra (Right) from Spot Marked with Yellow Cross.

Figure 9. Sample 4C-13-1, Aggregate of Thorium-Rich Material: Backscattered Electron Image (Left), Secondary Electron Image (Center), and Energy Dispersive Spectrometry Spectra (Right) from Spot Marked with Yellow Cross.............................................

Figure 10. Sample 4C-13-1: Single Crystal of Sodium-Calcium Carbonate or Oxalate (Left) and Energy Dispersive Spectrometry Spectra (Right) from Spot Marked with Yellow Cross....... 


\section{List of Terms}

\section{Acronyms and Abbreviations}

$\begin{array}{ll}\text { BEI } & \text { backscattered electron image } \\ \text { C-104 } & \text { tank 241-C-104 } \\ \text { EDS } & \text { energy dispersive X-ray detector } \\ \text { PSEM } & \text { personal scanning electron microscope } \\ \text { SEI } & \text { secondary electron image } \\ \text { SEM } & \text { scanning electron microscopy } \\ \text { TGA } & \text { thermogravimetric analysis } \\ \text { XRD } & \text { X-ray diffraction }\end{array}$




\section{INTRODUCTION}

At the request of Advanced Technologies and Laboratories International, Inc. and Tank Waste Inventory and Characterization personnel, one solid grab sample from closure sampling in Riser 7 of tank 214-C-104 (C-104) was examined to determine the solid phases that were present. The sample was analyzed using X-ray diffraction (XRD) and scanning electron microscopy (SEM). The purpose of this analysis was to see if the presence of hydrated phases could provide a possible explanation for the high moisture content obtained from thermogravimetric analysis (TGA) (see Appendix A). The TGA sample split had $11.5 \%$ water added by weight to prevent dispersion of the dry particulate.

Sample S13T003832 was a split from the homogenized grab sample 4C-13-1. It consisted of mostly light tan, granular solids with a few small white and reddish/brown particles. This split had not had additional water added. Once dried, the appearance was that of a homogeneous, light tan, fine solid.

\section{X-RAY DIFFRACTION ANALYSIS}

A fraction of the sample was ground as required, placed in the well of a quartz zero-background slide, compressed with the plane of a glass slide, fixed with collodion binder, and allowed to dry. Preparation and analysis by XRD was performed by J. A. Pestovich during the period April 11-15, 2013, in accordance with ATS-LT-507-103, "222-S Laboratory X-Ray Diffractometry (XRD) Using the Rigaku ${ }^{1}{ }^{1}$ MiniFlex II." Refer to laboratory notebook HNF-N-710-1, "Rigaku ${ }^{\circledR}$ MiniFlex II X-Ray Diffractometer (XRD) Maintenance and Operations (GD400212)," page 23, for test information and specifics. The sample compositions reported below are relative amounts based upon all the crystalline species present in each individual sample.

S13T003832 (4C-13-1). The major phases of the sample were identified as gibbsite $\left[\mathrm{Al}(\mathrm{OH})_{3}\right]$ and thermonatrite $\left[\mathrm{Na}_{2} \mathrm{CO}_{3} \cdot \mathrm{H}_{2} \mathrm{O}\right]$. Natrophosphate $\left[\mathrm{Na}_{7} \mathrm{~F}\left(\mathrm{PO}_{4}\right)_{2} \cdot 19 \mathrm{H}_{2} \mathrm{O}\right]$ and cancrinite $\left[\mathrm{Na}_{6} \mathrm{Ca}_{2} \mathrm{Al}_{6} \mathrm{Si}_{6} \mathrm{O}_{24}\left(\mathrm{CO}_{3}\right) \cdot 2.2 \mathrm{H}_{2} \mathrm{O}\right]$ were identified as minor phases, and clarkeite $\left[\mathrm{Na}\left(\left(\mathrm{UO}_{2}\right) \mathrm{O}\right)(\mathrm{OH}) \cdot \mathrm{H}_{2} \mathrm{O}\right]$ appeared as a trace phase.

\section{Chemical Name}

Aluminum Hydroxide

Sodium Carbonate Monohydrate

Sodium Fluoride Phosphate Hydrate

Sodium Calcium Aluminosilicate Carbonate

Sodium Uranium Oxide Hydroxide Hydrate

\begin{tabular}{l} 
Mineral Name \\
\hline Gibbsite \\
Thermonatrite \\
Natrophosphate \\
Cancrinite \\
Clarkeite
\end{tabular}

$\underline{\text { Formula }}$

$\mathrm{Al}(\mathrm{OH})_{3}$

$\mathrm{Na}_{2} \mathrm{CO}_{3} \cdot \mathrm{H}_{2} \mathrm{O}$

$\mathrm{Na}_{7} \mathrm{~F}\left(\mathrm{PO}_{4}\right)_{2} \cdot 19 \mathrm{H}_{2} \mathrm{O}$

$\mathrm{Na}_{6} \mathrm{Ca}_{2} \mathrm{Al}_{6} \mathrm{Si}_{6} \mathrm{O}_{24}\left(\mathrm{CO}_{3}\right) \cdot 2.2 \mathrm{H}_{2} \mathrm{O}$

$\mathrm{Na}\left(\left(\mathrm{UO}_{2}\right) \mathrm{O}\right)(\mathrm{OH}) \cdot \mathrm{H}_{2} \mathrm{O}$

\begin{tabular}{l} 
〜Rel. Amount \\
\hline Major \\
Major \\
Minor \\
Minor \\
Trace
\end{tabular}

\footnotetext{
${ }^{1}$ Rigaku is a registered trademark of Rigaku Americas Corporation/USA, The Woodlands, Texas.
} 
Figure 1. X-Ray Diffraction Pattern, Sample S13T003832 (4C-13-1).

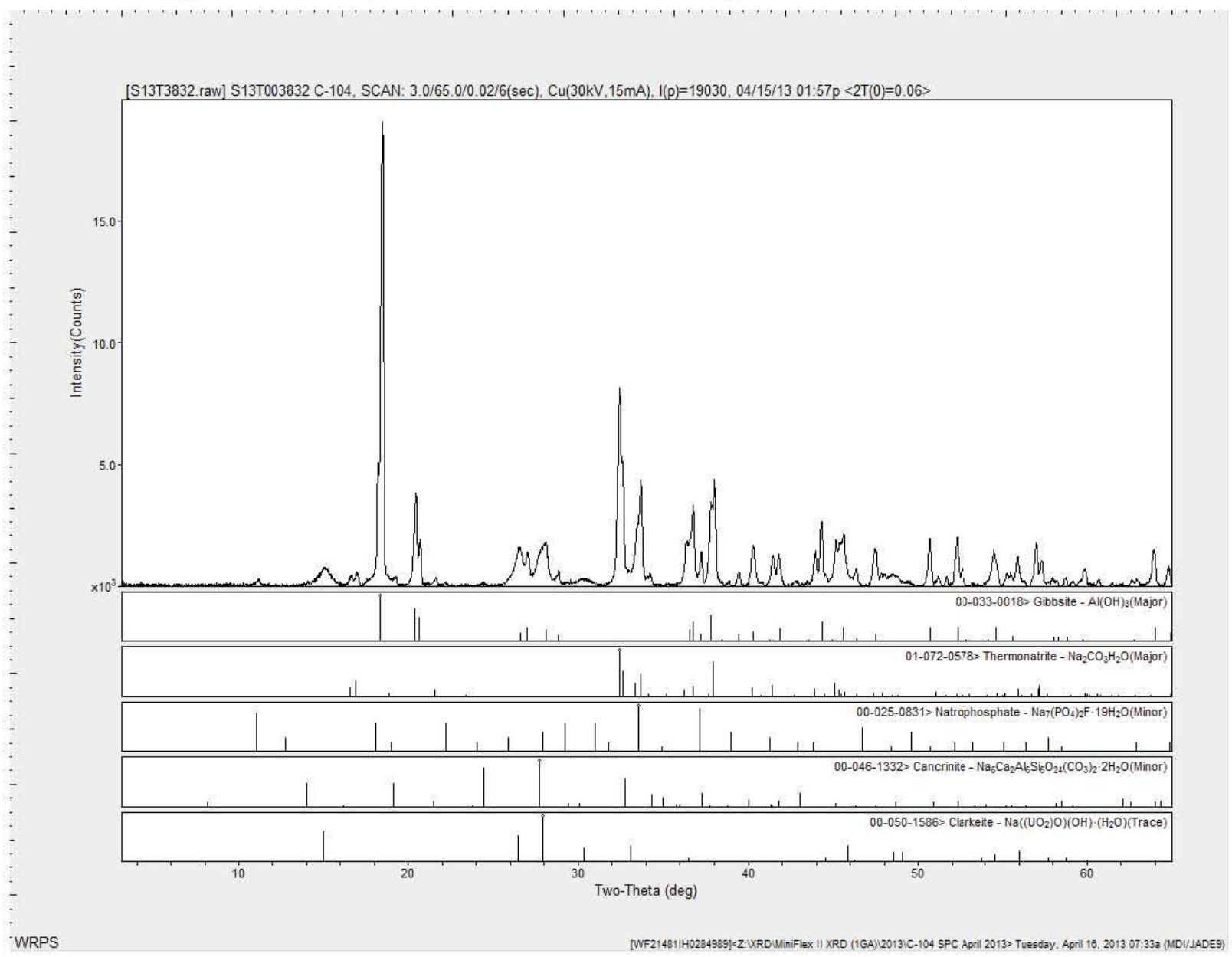

\section{SCANNING ELECTRON MICROSCOPY ANALYSIS}

Another portion of the dried sample was crushed lightly, and the dry solids were placed in a small petri dish. A SEM specimen was prepared by transferring the dried solids from the petri dish onto an aluminum SEM stub covered with an adhesive carbon tab. This specimen was coated with a thin layer of carbon by evaporative disposition. The resulting SEM specimen was examined on the ASPEX $\mathbb{R}^{2}$ personal scanning electron microscope (PSEM) equipped with an energy dispersive X-ray (EDS) detector. This instrument is located in Room 1-A at the 222-S Laboratory and is operated in accordance with the 222-S Laboratory Technical Procedure ATS-LT-161-100, "222-S Laboratory Sample Preparation and Operating Procedure for Scanning Electron Microscopes." Mr. G. A. Cooke performed the SEM analysis on April 11 and 15, 2013. Information pertaining to the preparation and analysis is contained in HNF-N-832-1, "Laboratory Controlled Notebook for SEM," page 184. The images used to illustrate the particle types that

\footnotetext{
${ }^{2}$ ASPEX is a registered trademark of Aspex Corporation, Delmont, Pennsylvania.
} 
were observed are all secondary electron images (SEI) unless identified as backscattered electron images (BEI).

The SEM specimen consisted of a number of large fragments that, upon closer examination, appeared to consist of aggregates of smaller particles. Figure 2 shows a group of these aggregates along with an EDS spectrum obtained by rastering the beam through the area delineated by the yellow box.

Figure 2. Sample 4C-13-1: Particle Aggregates (Left) and Energy Dispersive Spectrometry Spectra (Right) from Area in Yellow Box.
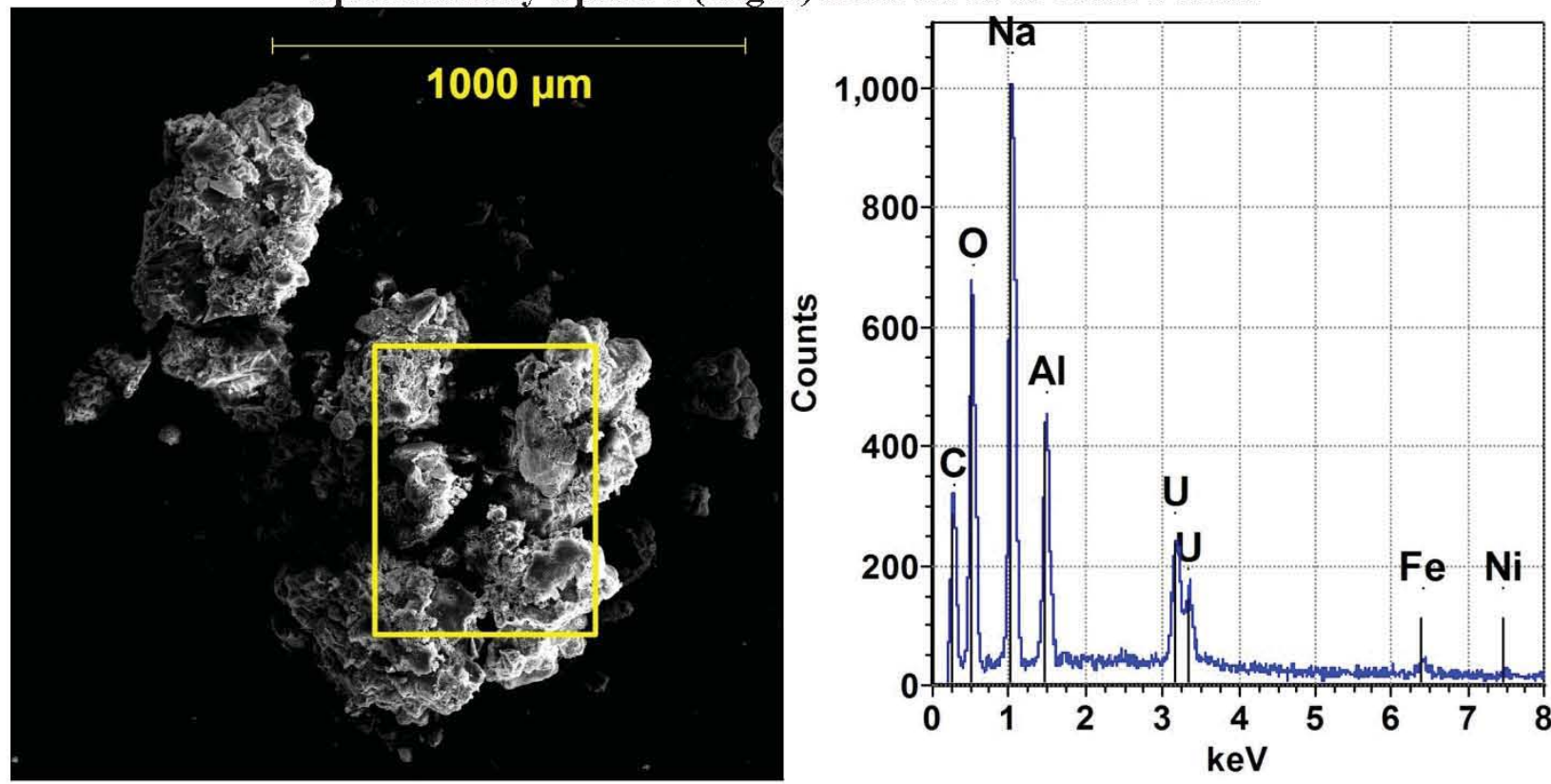

Some of these large particles have an external morphology that appears to be consistent with the natrophosphate (Figure 3). However, examination of the surface chemistry with the EDS detector shows these particles are typically covered with a sodium-rich phase (probably thermonatrite, as indicated by the XRD pattern). 
Figure 3. Sample 4C-13-1: Particle Aggregate Coated with Sodium Carbonate (Left) and Energy Dispersive Spectrometry Spectra (Right) from Spot Marked with Yellow Cross.
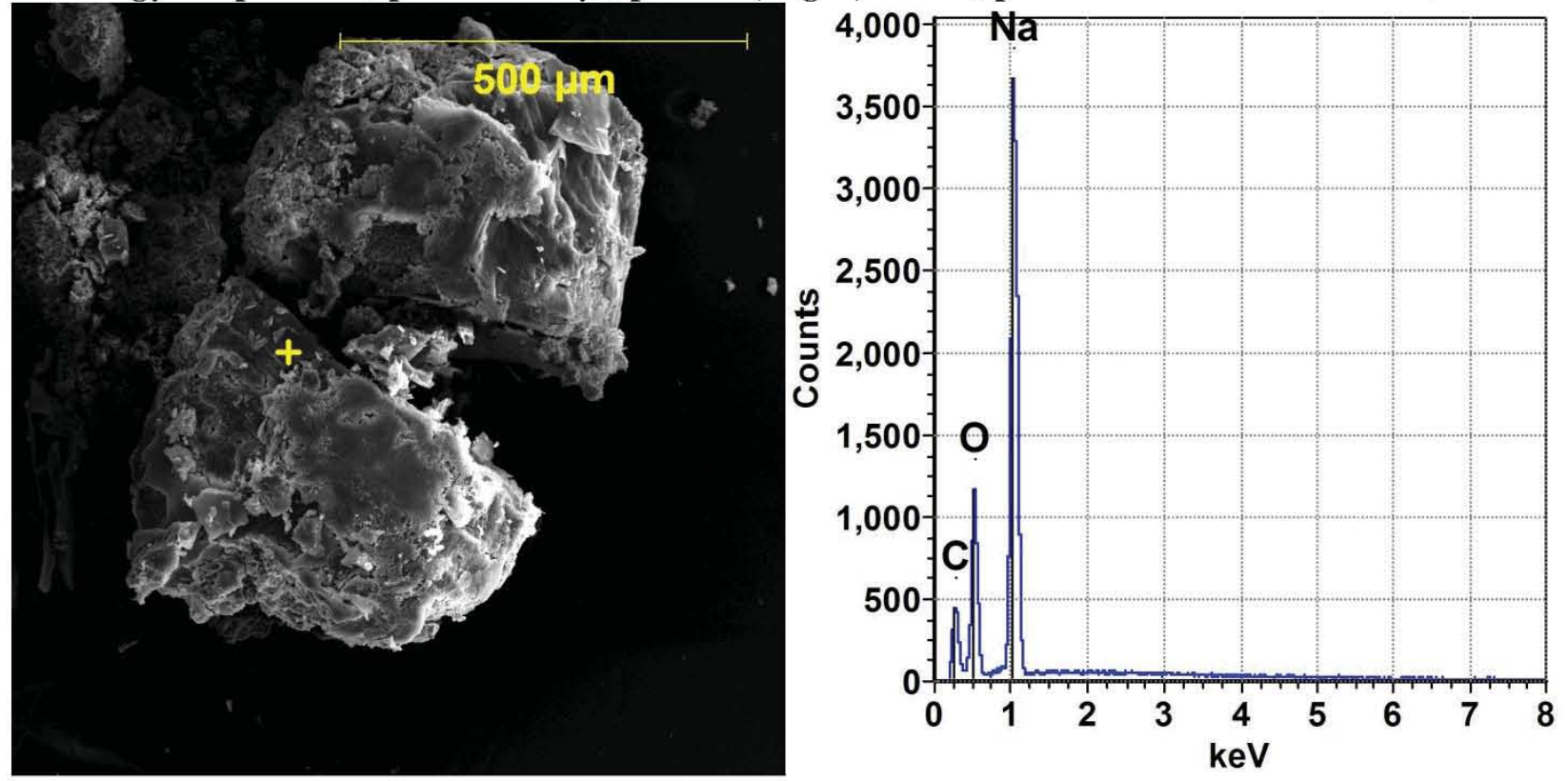

The sodium-rich material is uniformly fine grained and is mostly present as coatings (Figure 4), although discrete aggregates of sodium-rich material were observed (Figure 5).

Figure 4. Sample 4C-13-1: Close-up of Aggregate Surface (Left) and Energy Dispersive Spectrometry Spectra (Right) from Areas in Yellow Box.
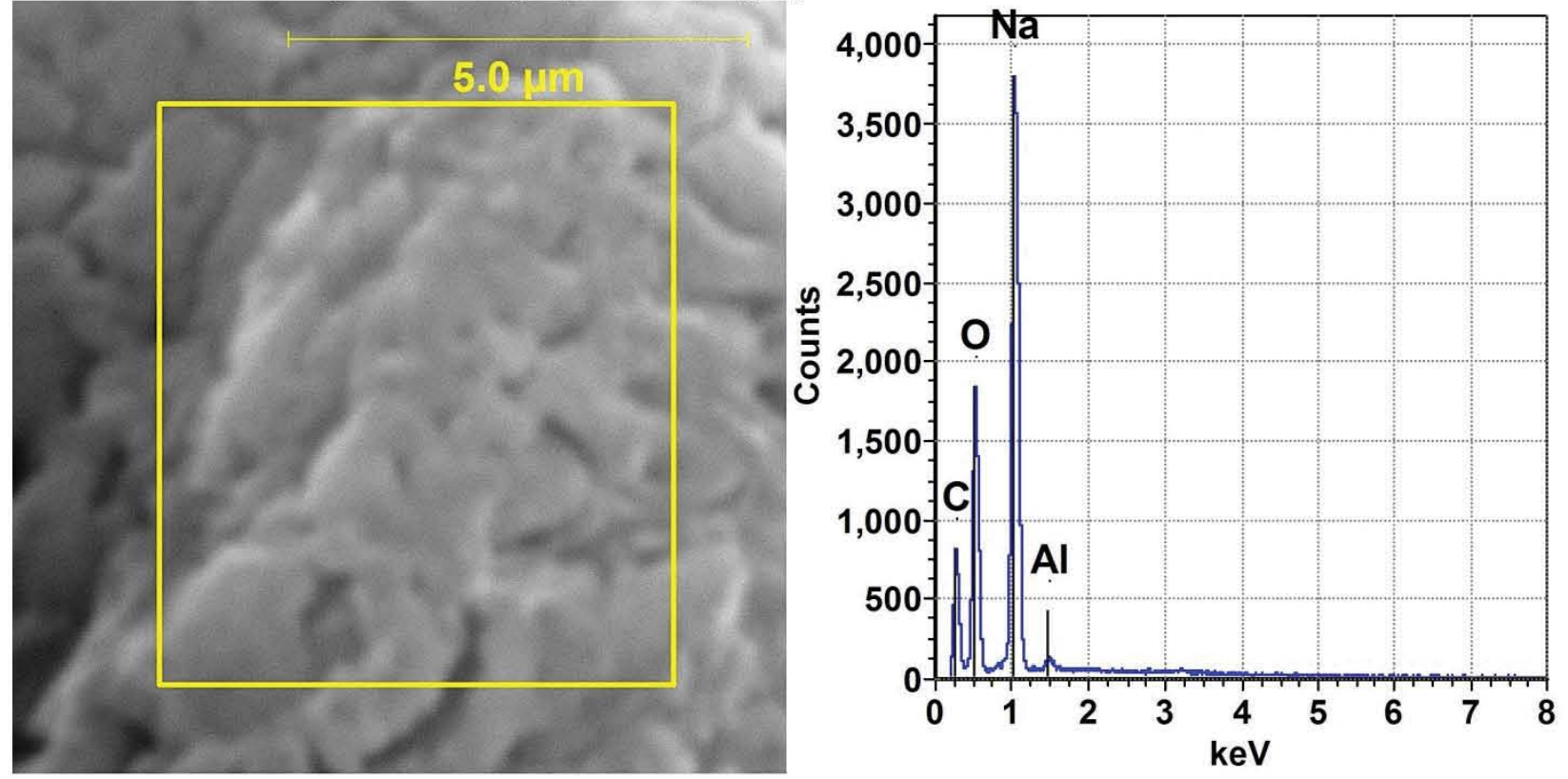
Figure 5. Sample 4C-13-1: Small Irregular Sodium Carbonate Aggregate (Left) and Energy Dispersive Spectrometry Spectra from Areas in Yellow Box (Right).
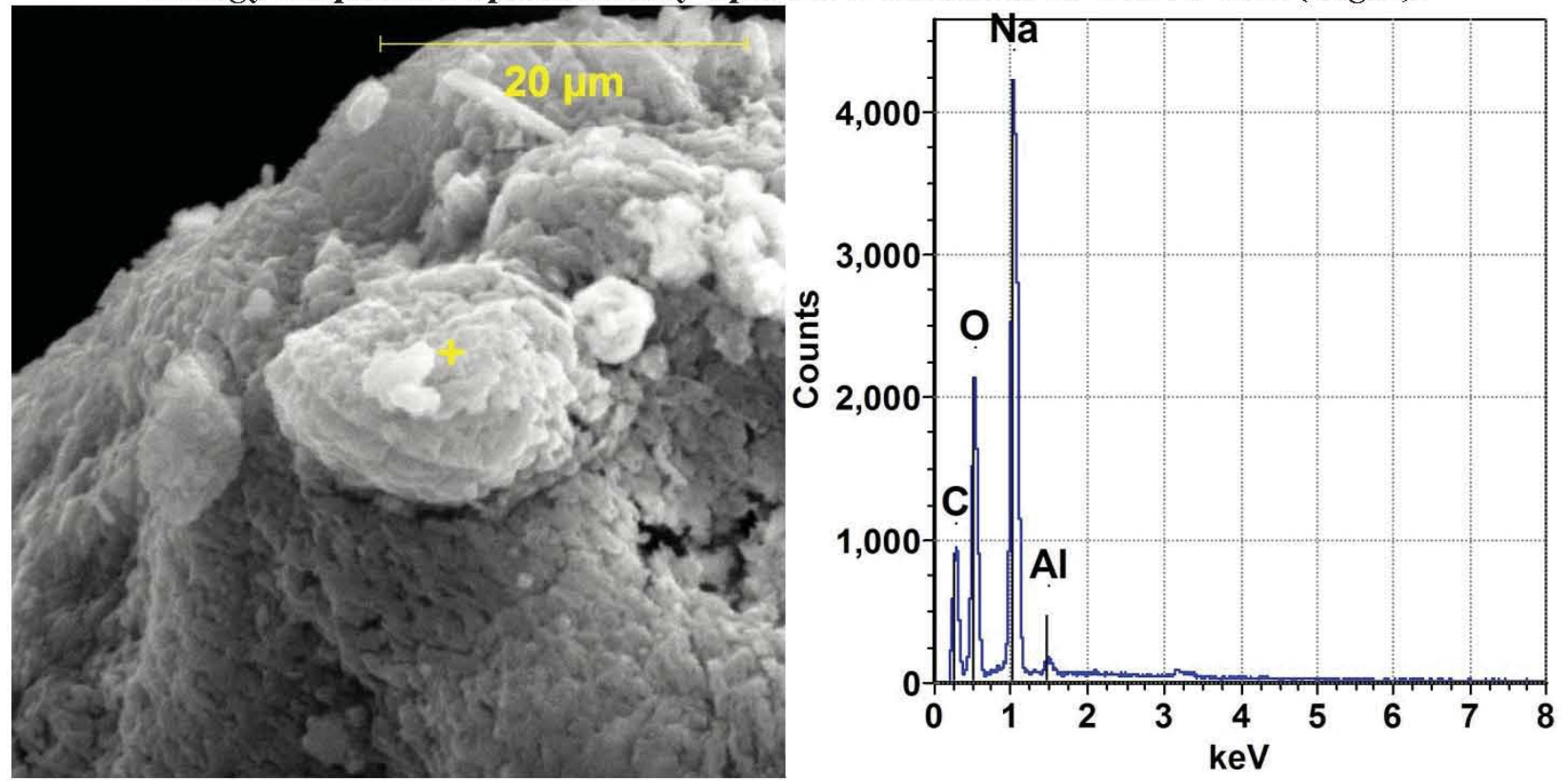

The next most common phases are aluminum-rich (Figure 6), usually recognized as small ( $<10$ micron) euhedral to subhedral crystals, and sodium-uranium-rich particulate, easily found by examining the particulate in BEI mode (Figure 7). These particles correspond to the gibbsite and clarkeite identified by the XRD analysis.

Figure 6. Sample 4C-13-1: Single Crystal of Gibbsite (Left) and Energy Dispersive Spectrometry Spectra (Right) from Spot Marked with Yellow Cross.
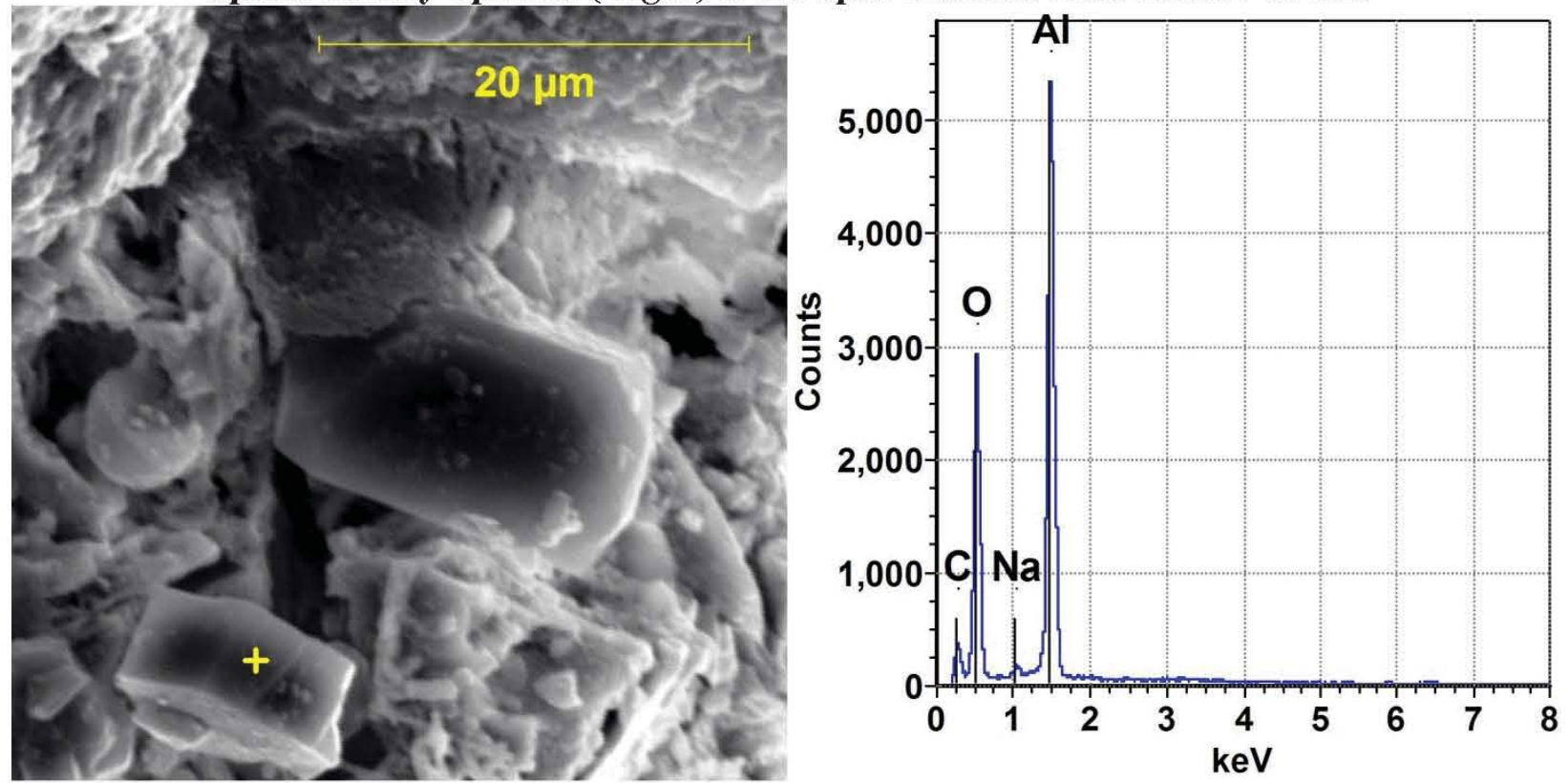
Figure 7. Sample 4C-13-1, Patch of Fine-Grained Clarkeite: Backscatter Electron Image (Left), Secondary Electron Image (Center), and Energy Dispersive Spectrometry Spectra (Right) from Spot Marked with Yellow Cross.

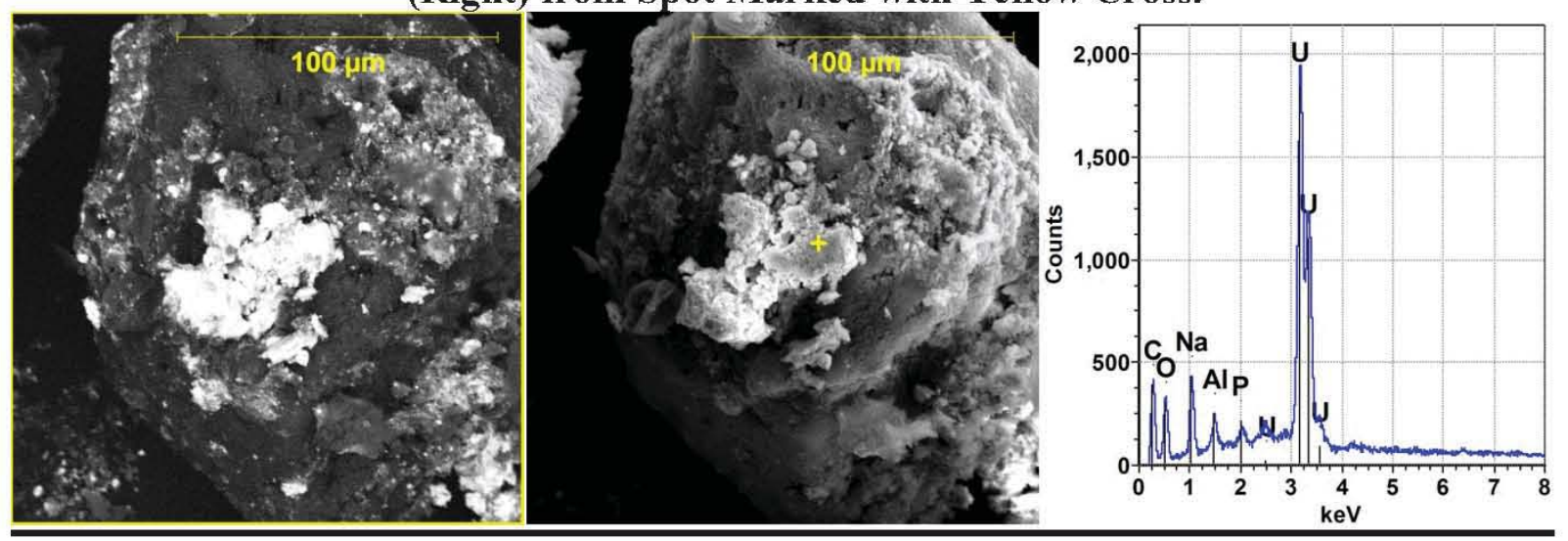

Less common phases, located on the SEM specimen, include iron-rich (also recognized as brighter than the surrounding particulate, Figure 8), thorium-rich (again showing up as brighter in BEI, Figure 9), and a sodium-calcium-rich particulate (Figure 10).

Figure 8. Sample 4C-13-1, Patch of Fine-Grained Iron Oxyhydroxide: Backscattered Electron Image (Left), Secondary Electron Image (Center), and Energy Dispersive Spectrometry Spectra (Right) from Spot Marked with Yellow Cross.
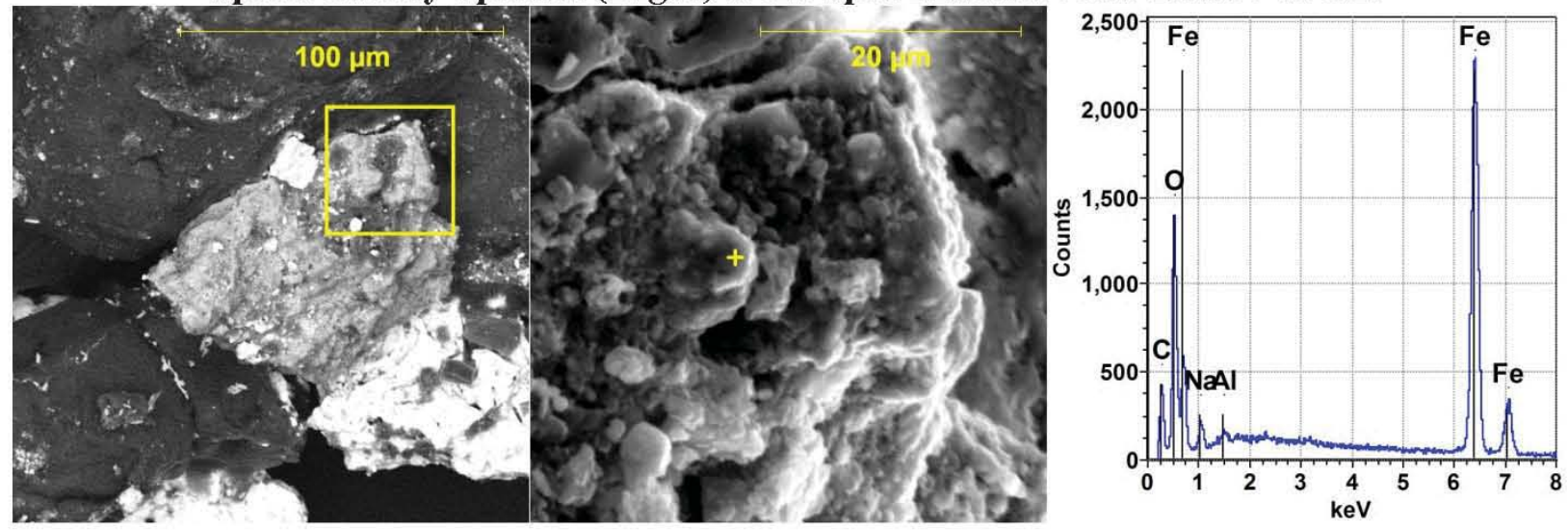
Figure 9. Sample 4C-13-1, Aggregate of Thorium-Rich Material: Backscattered Electron Image (Left), Secondary Electron Image (Center), and Energy Dispersive Spectrometry Spectra (Right) from Spot Marked with Yellow Cross.
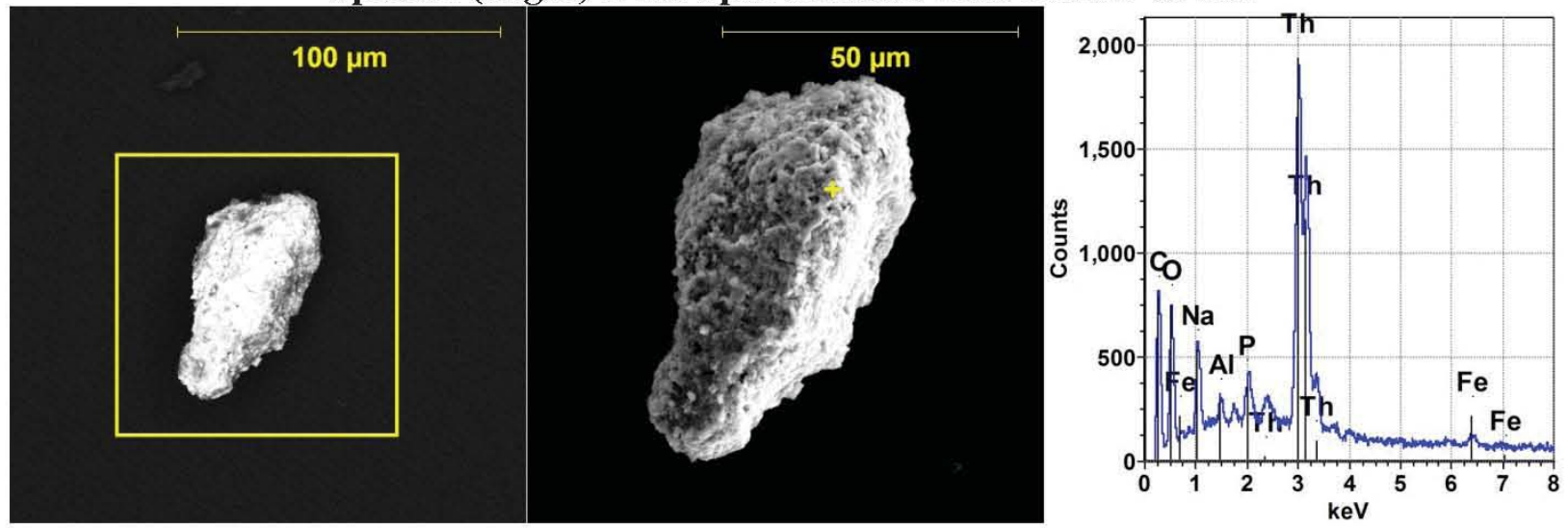

Figure 10. Sample 4C-13-1: Single Crystal of Sodium-Calcium Carbonate or Oxalate (Left) and Energy Dispersive Spectrometry Spectra (Right) from Spot Marked with Yellow Cross.
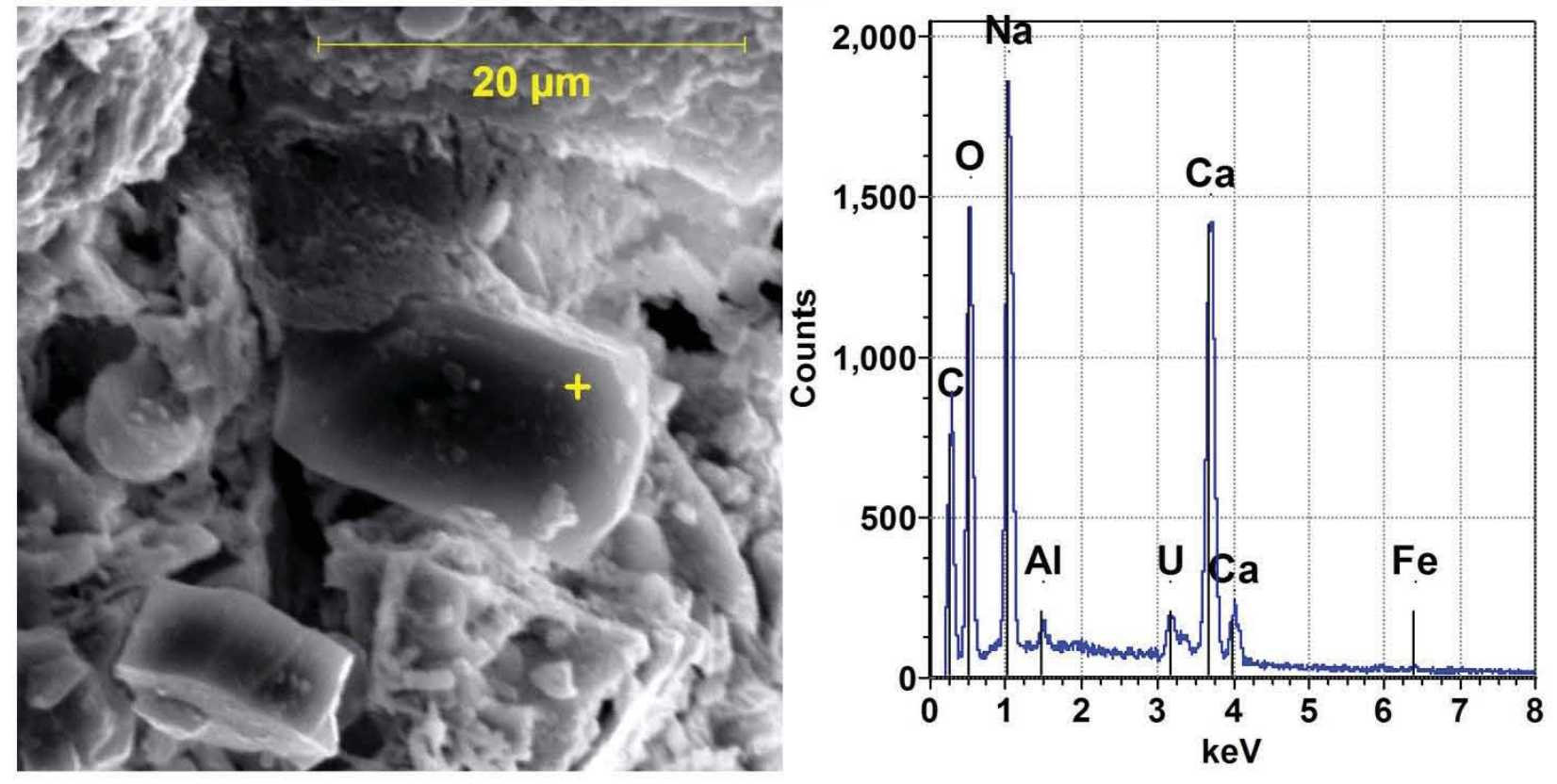

\section{DISCUSSION}

Solid phase characterization was performed on Sample S13T0003832 (4C-13-1) in order to seek an explanation for unusually high weight loss results from the TGA analysis. This sample was one of four grab samples taken from C-104 and analyzed at the 222-S Laboratory as directed by RPP-PLAN-44844, Sampling and Analysis Plan for Waste Solids in Tank 241-C-104 to Support Tank Closure. 
Analysis by XRD and SEM showed the sample to consist of aggregates of mostly fine-grained material cemented with thermonatrite $\left[\mathrm{Na}_{2} \mathrm{CO}_{3} \bullet \mathrm{H}_{2} \mathrm{O}\right]$. The thermonatrite and gibbsite $\left[\mathrm{Al}(\mathrm{OH})_{3}\right]$ were the major phases identified by XRD, and the SEM found coatings of fine-grained thermonatrite on the surface of the particle aggregates.

The SEM BEI imaging readily detected a sodium- and uranium-bearing compound that was consistent with the clarkeite $\left[\mathrm{Na}\left(\left(\mathrm{UO}_{2}\right) \mathrm{O}\right)(\mathrm{OH}) \bullet \mathrm{H}_{2} \mathrm{O}\right]$ identified as a trace phase by XRD. The broad XRD peaks associated with the clarkeite indicate that it is poorly crystalline. The discrepancy between the SEM, which showed the uranium phase to be common, and the XRD, which found only trace amounts, can be explained if most of the uranium-bearing phase is non-crystalline.

Natrophosphate $\left[\mathrm{Na}_{7} \mathrm{~F}\left(\mathrm{PO}_{4}\right)_{2} \cdot 19 \mathrm{H}_{2} \mathrm{O}\right]$ and cancrinite $\left[\mathrm{Na}_{6} \mathrm{Ca}_{2} \mathrm{Al}_{6} \mathrm{Si}_{6} \mathrm{O}_{24}\left(\mathrm{CO}_{3}\right) \cdot 2.2 \mathrm{H}_{2} \mathrm{O}\right]$ were identified as minor phases by XRD and could not be located on the SEM specimen. This is probably due to the heavy coating of thermonatrite that was ubiquitous on the larger particles.

Iron-rich and thorium-rich particulate were observed on the SEM specimen. No peaks on the XRD pattern could be attributed to compounds with these chemical elements. This is due to their low concentrations, their lack of crystal structure, or both.

The phases observed are all consistent with the chemical analyses for these samples (report in preparation). They are also consistent with the phases found in previous $\mathrm{C}$-farm heel samples (LAB-RPT-11-00008, Solid Phase Characterization of Heel Samples from Tank 241-C-110; LAB-RPT-13-00002, Solid Phase Characterization of Tank 241-C-108 Residual Waste Solids Samples).

However, the particulate in Sample 4C-13-1 is somewhat unusual in that it consists of porous aggregates of very fine-grained material. This may play some role in the TGA results, since the abundant pore space may allow substantial water to persist in the aggregate particles and yet still appear to be dry. These porous aggregates would act to absorb water, causing the particulate to appear dryer than it really is.

\section{REFERENCES}

ATS-LT-161-100, Rev. F-0, "222-S Laboratory Sample Preparation and Operating Procedure for Scanning Electron Microscopes," Washington River Protection Solutions LLC, Richland, Washington.

ATS-LT-507-103, Rev. B-0, "222-S Laboratory X-Ray Diffractometry (XRD) Using the Rigaku MiniFlex II," Washington River Protection Solutions LLC, Richland, Washington.

HNF-N-710-1, Date of Issue 12/28/2010, "Rigaku MiniFlex II X-Ray Diffractometer (XRD) Maintenance and Operations (GD400212),"Washington River Protection Solutions LLC, Richland, Washington. 
HNF-N-832-1, "Laboratory Controlled Notebook for SEM," Washington River Protection Solutions LLC, Richland, Washington.

LAB-RPT-11-00008, 2011, Solid Phase Characterization Of Heel Samples From Tank 241-C-110, Rev. 0, Washington River Protection Solutions LLC, Richland, Washington.

LAB-RPT-13-00002, 2013, Solid Phase Characterization of Tank 241-C-108 Residual Waste Solids Samples, Rev. 0, Washington River Protection Solutions LLC, Richland, Washington.

RPP-PLAN-44844, 2013, Sampling and Analysis Plan for Waste Solids in Tank 241-C-104 to Support Tank Closure, Rev. 2, Washington River Protection Solutions LLC, Richland, Washington. 


\section{Electronically Approved by:}

UserName: Cooke, Gary (h0410221)

Title: APD Chemist

Date: Thursday, 23 May 2013, 09:32 AM Pacific Time

Meaning: Approved by the author or delegate

UserName: Pestovich, John (h0284989)

Title:

Date: Thursday, 23 May 2013, 09:58 AM Pacific Time

Meaning: Additional approval obtained

UserName: Nguyen, Duc (h0051515)

Title: Flowsheet and Process Models

Date: Tuesday, 28 May 2013, 07:07 AM Pacific Time

Meaning: Approved by the customer or delegate

UserName: Greenough, Keith (h0068375)

Title: Laboratory Facilities

Date: Tuesday, 04 June 2013, 08:58 AM Pacific Time

Meaning: Approved by the Facility Manager or delegate

UserName: Seidel, Cary (h0009079)

Title: APD Manager

Date: Tuesday, 04 June 2013, 09:18 AM Pacific Time

Meaning: Approved by the Group Manager or delegate 


\section{DISTRIBUTION SHEET}

To

John Pestovich

Steve G. McKinney

Dan Herting

Duc M. Nguyen

Cary M. Seidel

John R. Prilucik

Jacob G. Reynolds

Jurgen H. Rasmussen

From
Gary A. Cooke

Gary A. Cooke

Project Title/Work Order

LAB-RPT-13-00005 Solid Phase Characterizati
From Tank 241-C-104 Closure Sampling Event

Name

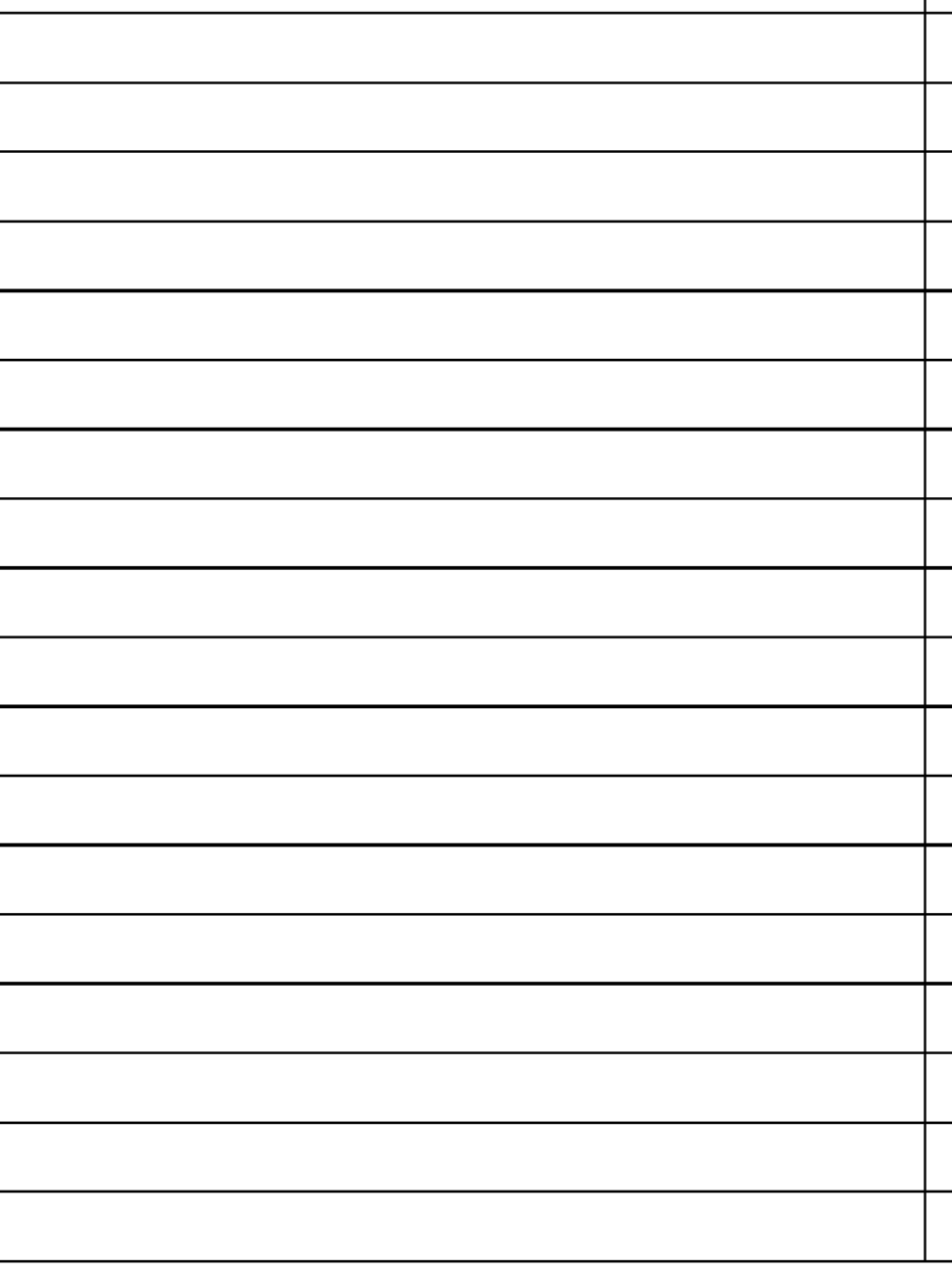

sample 4C-13-1

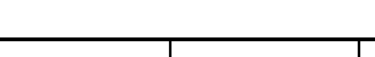

\begin{tabular}{ll} 
Page & $\underline{1}$ Of $\underline{1}$ \\
\hline Date & $05 / 28 / 2013$
\end{tabular}

EDT No.

NA

ECN No

NA

(

Attach.I MSIN With All Text Only Attach.

Appendix Only

EDT/ECN

\begin{tabular}{l|l}
$\mathrm{T} 6-05$ & $\mathrm{X}$
\end{tabular}

T6-05

\begin{tabular}{l|l}
$\mathrm{T} 6-05$ & $\mathrm{X}$
\end{tabular}

\begin{tabular}{l|l}
$\mathrm{R} 2-58$ & $\mathrm{X}$
\end{tabular}

T6-14 X

\begin{tabular}{l|l} 
T6-05 & $\mathrm{X}$
\end{tabular}

R2-58

R2-58
X

X

X

$\mathrm{X}$

X

$\mathrm{X}$

X

X

